\title{
Fog scavenging of organic and inorganic aerosol in the Po Valley
}

\author{
S. Gilardoni ${ }^{1}$, P. Massoli ${ }^{4}$, L. Giulianelli ${ }^{1}$, M. Rinaldi ${ }^{1}$, M. Paglione ${ }^{1}$, F. Pollini ${ }^{1}$, C. Lanconelli ${ }^{1}$, V. Poluzzi ${ }^{2}$, \\ S. Carbone ${ }^{3}$, R. Hillamo ${ }^{3}$, L. M. Russell ${ }^{5}$, M. C. Facchini ${ }^{1}$, and S. Fuzzi ${ }^{1}$ \\ ${ }^{1}$ Italian National Research Council - Institute of Atmospheric Sciences and Climate, Bologna, Italy \\ ${ }^{2}$ Agenzia Regionale per la Prevenzione e l'Ambiente ARPA, Bologna, Italy \\ ${ }^{3}$ Finnish Meteorological Institute, Air quality, Helsinki, Finland \\ ${ }^{4}$ Aerodyne Research, Billerica, MA, USA \\ ${ }^{5}$ Scripps Institute of Oceanography, University of California-San Diego, La Jolla, CA, USA
}

Correspondence to: S. Gilardoni (s.gilardoni@isac.cnr.it)

Received: 19 December 2013 - Published in Atmos. Chem. Phys. Discuss.: 21 February 2014

Revised: 29 May 2014 - Accepted: 2 June 2014 - Published: 9 July 2014

\begin{abstract}
The interaction of aerosol with atmospheric water affects the processing and wet removal of atmospheric particles. Understanding such interaction is mandatory to improve model description of aerosol lifetime and ageing. We analyzed the aerosol-water interaction at high relative humidity during fog events in the Po Valley within the framework of the Agenzia Regionale per la Prevenzione e l'Ambiente (ARPA) - Emilia Romagna supersite project. For the first time in this area, the changes in particle chemical composition caused by fog are discussed along with changes in particle microphysics.

During the experiment, 14 fog events were observed. The average mass scavenging efficiency was $70 \%$ for nitrate, $68 \%$ for ammonium, $61 \%$ for sulfate, $50 \%$ for organics, and $39 \%$ for black carbon. After fog formation, the interstitial aerosol was dominated by particles smaller than $200 \mathrm{~nm} D_{\text {va }}$ (vacuum aerodynamic diameter) and enriched in carbonaceous aerosol, mainly black carbon and water-insoluble organic aerosol.

For each fog event, the size-segregated scavenging efficiency of nitrate and organic aerosol (OA) was calculated by comparing chemical species size distribution before and after fog formation. For both nitrate and OA, the size-segregated scavenging efficiency followed a sigmoidal curve, with values close to zero below $100 \mathrm{~nm} D_{\text {va }}$ and close to 1 above $700 \mathrm{~nm} D_{\text {va }}$. OA was able to affect scavenging efficiency of nitrate in particles smaller than $300 \mathrm{~nm} D_{\text {va }}$. A linear correlation between nitrate scavenging and particle hygroscopicity $(\kappa)$ was observed, indicating that $44-51 \%$ of the variability
\end{abstract}

of nitrate scavenging in smaller particles (below $300 \mathrm{~nm} D_{\text {va }}$ ) was explained by changes in particle chemical composition.

The size-segregated scavenging curves of OA followed those of nitrate, suggesting that organic scavenging was controlled by mixing with water-soluble species. In particular, functional group composition and OA elemental analysis indicated that more oxidized OA was scavenged more efficiently than less oxidized OA. Nevertheless, the small variability of organic functional group composition during the experiment did not allow us to discriminate the effect of different organic functionalities on OA scavenging.

\section{Introduction}

Fog scavenging is the process by which atmospheric particles transfer into the liquid phase of fog droplets. Fog scavenging affects particle microphysical and chemical properties, which are relevant to predict the effect of aerosol on climate and air quality. Indeed, fog scavenging reduces aerosol loading by promoting wet removal (Collett et al., 2001) and modifies aerosol hygroscopicity and particle size distribution by selectively removing water-soluble species (Collett et al., 2008). In addition, particle water uptake associated with fog promotes aerosol processing and secondary aerosol formation through heterogeneous-phase chemistry (Kaul et al., 2011; Ervens et al., 2011; Li et al., 2013).

Fog scavenging can take place through both impaction scavenging and nucleation scavenging. Impaction scavenging occurs when interstitial particles are incorporated into fog 
droplets as a consequence of Brownian diffusion, inertial impaction, and phoretic effects. In a supersaturated atmosphere, aerosol particles can be activated to form fog droplets and be scavenged by nucleation. Generally, nucleation scavenging dominates in-cloud and in-fog aerosol scavenging (Seinfeld and Pandis, 1998; Elbert et al., 2000).

Several fog experiments have proven that nucleation scavenging is the dominant aerosol scavenging mechanism in the Po Valley. Fuzzi et al. (1988) observed that sulfate scavenging efficiency was lower compared to in-cloud measurements and attributed this difference to the lower supersaturation of fog compared to clouds. In the same area, Hallberg et al. (1992) observed that fog scavenging efficiency of different chemical compounds was related to their water solubility, with higher scavenging for water-soluble species like sulfate, and lower for carbonaceous hydrophobic compounds like elemental carbon. During the same experiment, the comparison of particle number size distribution in and out of fog showed that fog scavenging did not affect smaller particle concentration (mobility diameter $\mathrm{D}_{\mathrm{m}}$ below $300 \mathrm{~nm}$ ) but did efficiently remove particles larger than $700 \mathrm{~nm} \mathrm{D}_{\mathrm{m}}$, leading to the conclusion that aerosol scavenging was mainly driven by nucleation (Noone et al., 1992). Elbert et al. (2000) investigated the relationship between atmospheric liquid water content and chemical composition of fog-water samples, and concluded that nucleation scavenging was the dominant particle removal mechanism.

The critical supersaturation required to nucleate fog droplets is usually around 0.01 and $0.03 \%$ (Noone et al., 1992; Ming and Russell, 2004). However, in highly polluted environments like the Po Valley, soluble species in the gas phase and organic solutes in the liquid droplets might decrease the critical supersaturation required for particle activation, making cloud and fog formation possible even at ambient relative humidity below $100 \%$ (Shulman et al., 1996; Laaksonen et al., 1998; Facchini et al., 1999b).

Although an increasing number of experiments investigated nucleation at supersaturation typical of clouds, little is known about the relative importance of chemistry and microphysics on cloud condensation nuclei (CCN) activity at supersaturation close to zero, which is typical of fog. Some studies show that particle size explained more than $84 \%$ of the $\mathrm{CCN}$ variability at a supersaturation of $0.4 \%$. (Dusek et al., 2006). Other studies instead suggest that particle chemical composition can explain $40 \%$ of the critical diameter variability at a supersaturation of $0.44 \%$; at lower supersaturation the influence of particle composition is expected to be even higher (Quinn et al., 2008). More recently, observations performed during a wide number of aircraft campaigns and ground-based experiments led to the conclusion that both size and compositional information are required to predict particle CCN activity (Hudson, 2007; Levin et al., 2014).

At the same time, the effect of fog scavenging on particle chemical composition, and especially on OA, is still poorly understood (Herckes et al., 2007). Facchini et al. (1999a) studied the distribution of different classes of carbonaceous species between interstitial aerosol and fog water, reporting a preferential partitioning of water-soluble organic carbon in fog droplets. Even when impaction scavenging is the dominant mechanism, a preferential removal of hydrophilic organic species was observed (Maria and Russell, 2005). Collett et al. (2008) investigated organic aerosol scavenged during four fog events in central California and observed a slight positive correlation with liquid water content (LWC). However, no information on particle microphysics and mixing state with other chemical constituents was available in these studies.

This paper analyzes the fog scavenging efficiency of major chemical components in fine particles through field observations in the Po Valley during fall of 2011 within the framework of the ARPA-Emilia Romagna supersite project. For the first time in this area, the effects of fog on particle chemistry were investigated at high time resolution, with particle microphysics taken into account. The objective of this study is to analyze the effect of scavenging on the chemical and the microphysical properties of aerosol after fog dissipation, and to investigate the role of chemical composition and mixing state of fine particles on nitrate scavenging and OA scavenging. In particular, scavenging of nitrate and OA is quantitatively discussed as a function of size distribution of the different chemical components and organic functional group composition.

\section{Methods}

\subsection{Sampling site}

The measurements described in this work were performed at the meteorological station Giorgio Fea in San Pietro Capofiume, a rural background site located at about $30 \mathrm{~km}$ northeast of Bologna, in the eastern part of the Po Valley (northern Italy). Aerosol characterization was performed from 14 November to 1 December 2011. In the Po Valley, fall is usually characterized by stable meteorological conditions, with high relative humidity and low temperature, that lead to frequent fog events that often last for several hours (Fuzzi et al., 1992).

The meteorological conditions observed during the measurement period are reported in Fig. 1. High pressure and stable weather conditions characterized the entire campaign. Winds were generally below $2 \mathrm{~m} \mathrm{~s}^{-1}$ and temperature averaged $3{ }^{\circ} \mathrm{C}$, with values around $10^{\circ} \mathrm{C}$ during daytime and $0^{\circ} \mathrm{C}$ at nighttime. Relative humidity $(\mathrm{RH})$ was often close to $100 \%$ throughout both daytime and nighttime, especially before 23 November.

Liquid water content (LWC) was measured continuously with a particulate volume monitor, PVM-100 (Gerber, 1991), at $1 \mathrm{~min}$ time resolution. LWC higher than $0.08 \mathrm{~g} \mathrm{~m}^{-3}$ is an indicator of fog presence. The LWC time trend is reported in 


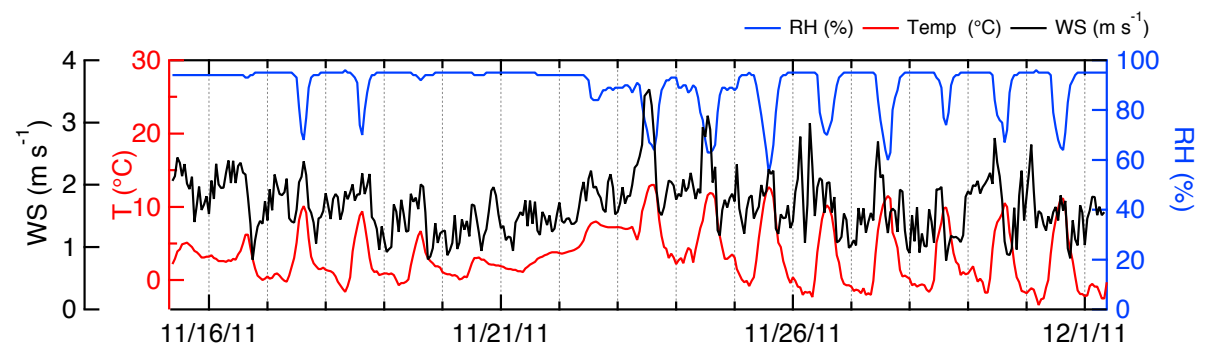

Figure 1. Time trends of temperature (red), relative humidity (blue), and wind speed (black) at San Pietro Capofiume during the research campaign.

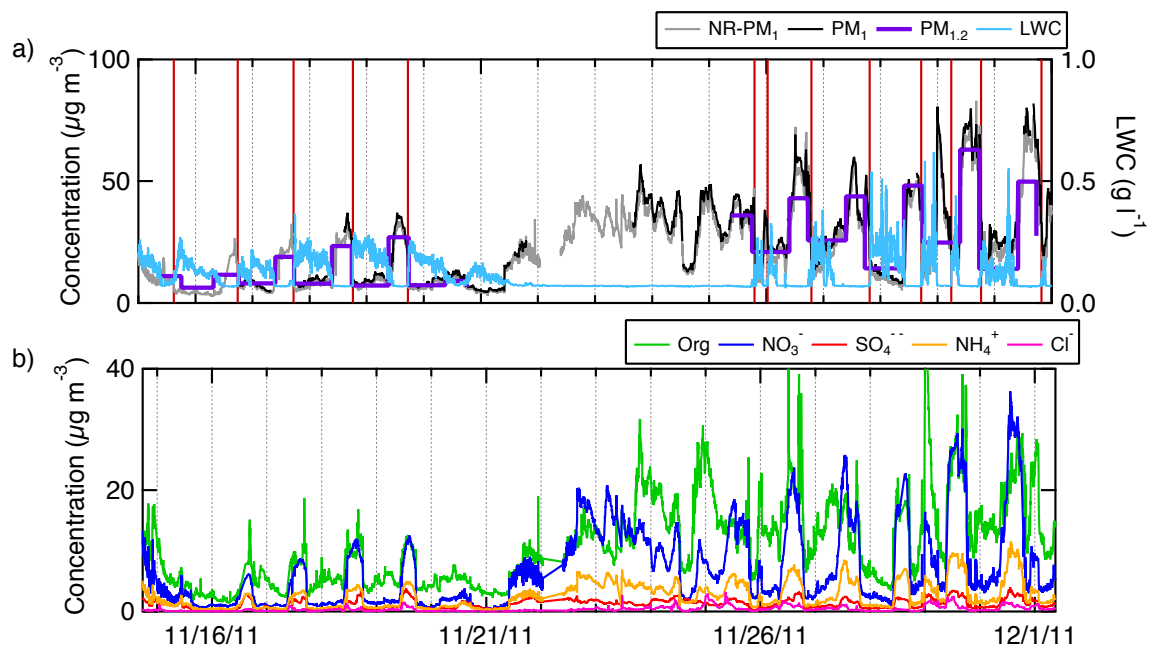

Figure 2. (a) Time trends of liquid water content (light blue), non refractory $\mathrm{PM}_{1}$ (grey), $\mathrm{PM}_{1}$ (purple), and chemically reconstructed $\mathrm{PM}_{1.2}$ from offline analysis (thick black); red vertical lines identify the beginning of fog events. (b) Time trend of chemical species from AMS analysis: organics (green), nitrate (blue), sulfate (red), ammonium (orange), and chloride (pink).

Fig. 2a and indicates that fog formed almost every evening around 17:00 local time (LT) and persisted during the greater part of the night until the following morning, disappearing around 09:00 LT. During the entire campaign, a total of 14 distinct fog events were identified.

\subsection{Aerosol sampling}

Size-segregated aerosol particles were sampled by a Berner impactor (flow rate $80 \mathrm{~L} \mathrm{~min}^{-1}$ ) on aluminum and Tedlar foils. The Berner impactor collects particles on five stages, corresponding to the following particle aerodynamic diameter cutoffs: $0.14,0.42,1.2,3.5$, and $10 \mu \mathrm{m}$. Sampling was performed continuously during the entire period. Each day we collected two samples: a daytime sample from 09:00 to 17:00 LT, and a nighttime one from 17:00 to 09:00 LT. Particles collected on aluminum foils were analyzed for carbonaceous aerosol content by means of a thermal technique, while samples collected on Tedlar were analyzed by means of ion chromatography for quantification of water-soluble inorganic species.

Submicron particles were collected on Teflon filters (37 mm diameter) downstream of a silica gel drier and a $\mathrm{PM}_{1}$ cut cyclone (flow rate $16.7 \mathrm{~L} \mathrm{~min}^{-1}$ ). One $24 \mathrm{~h}$ sample was collected daily from 09:00 to 09:00 LT. Three additional samples were collected each day from 09:00 to 13:00, from 13:00 to 17:00, and from 17:00 to 09:00 LT of the following morning.

Submicron particles were also sampled on prewashed and prebaked quartz-fiber filters (PALL, $9 \mathrm{~cm}$ size) using a dichotomous sampler (Universal Air Sampler, model 310, MSP Corporation) at a constant nominal flow of $300 \mathrm{~L} \mathrm{~min}^{-1}$ located at ground level. A total of 30 samples were collected between 15 and 30 November. Typically, two filters were sampled every day, with a daytime $\mathrm{PM}_{1}$ sample collected from 09:00 to 17:00 LT, and an evening/nighttime sample collected from 18:00 to 09:00 LT. Samples were stored in Petri dishes at $4{ }^{\circ} \mathrm{C}$ prior to analysis. 


\subsection{Offline aerosol chemical characterization}

Size-segregated concentrations of inorganic ions were measured by means of ion chromatography analysis of ultrapure water extracts of Tedlar substrates.

Water-soluble organic carbon (WSOC) was detected by analyzing the Tedlar substrate water extracts using a multi N/C 2100S (Analytik Jena, Germany) elemental analyzer. WSOC was quantified as the difference between total watersoluble carbon and soluble inorganic carbon. Total carbon (TC) was determined by the analysis of aluminum foil with the same technique. The detection limit was $0.2 \mu \mathrm{g}$ of carbon and the accuracy of the TC measurement was better than $5 \%$ for $1 \mu \mathrm{g}$ of carbon.

The dichotomous quartz-fiber filters were analyzed to identify organic molecular tracers using proton nuclear magnetic resonance (HNMR) spectroscopy according to Decesari et al. (2006).

Organic aerosol functional groups were analyzed by means of infrared spectrometry (Gilardoni et al., 2009; Russell et al., 2011). Teflon filters were analyzed by means of Fourier transform infrared (FTIR) spectrometry in transmission mode in the region $400-4000 \mathrm{~cm}^{-1}$, using a Bruker TENSOR 27 FTIR spectrometer equipped with a deuterated triglycine sulfate (DTGS) detector. Spectrum resolution was $4 \mathrm{~cm}^{-1}$. Filters were scanned prior and subsequent to aerosol collection in order to remove Teflon absorption signals from the aerosol absorption spectrum. Aerosol spectra were then processed with an automated algorithm to perform baseline, peak fitting, and peak integration according to the procedure described by Russell et al. (2009). The functional group identified during the experiment included alkyl $\left(-\mathrm{CH}_{2}-\right)$, carboxyl $(-\mathrm{COOH})$, hydroxyl $(-\mathrm{OH})$, amine ($\mathrm{NH}-)$, and organonitrate $\left(\mathrm{C}-\mathrm{NO}_{3}\right)$ groups. Aromatic and unsaturated aliphatic $(=\mathrm{CH}-)$, carbonyl $(\mathrm{C}=\mathrm{O})$, and organosulfate $\left(\mathrm{C}-\mathrm{OSO}_{3}\right)$ moieties were below detection limit at all times. Absorption intensity was converted into mass according to Lambert-Beer equation and based on calibration with standard representative of atmospheric aerosol organic molecules. Organic mass was defined as the sum of the different organic functional groups. Elemental composition of organic aerosol was instead determined based on the elemental composition of each group.

\subsection{Online aerosol chemical characterization}

The size-resolved chemical composition of submicron aerosol particles was characterized online by a highresolution time-of-flight aerosol mass spectrometer (HRTOF-AMS) (DeCarlo et al., 2006) and a soot particle aerosol mass spectrometer (SP-AMS) (Onasch et al., 2012).

The HR-TOF-AMS provided size-resolved chemical measurements of the nonrefractory sulfate, nitrate, ammonium, chloride, and organic mass in submicron particles $\left(\mathrm{NR}-\mathrm{PM}_{1}\right)$. The HR-TOF-AMS was operating by alternating between
"V" (higher sensitivity, lower mass resolution) and "W" (lower sensitivity, higher mass resolution) ion path modes every $5 \mathrm{~min}$. The concentrations reported here correspond to the data collected in $\mathrm{V}$ mode. While operating in $\mathrm{V}$ mode, the HR-TOF-AMS acquires information about size distribution of particles, or particle time of flight (pToF) (Jimenez et al., 2003). The AMS has an effective $50 \%$ cutoff for particle sizes below 80 and above $600 \mathrm{~nm}$ in vacuum aerodynamic diameter, $D_{\text {va }}$, as determined by the transmission characteristics of the standard aerodynamic lens (Liu et al., 2007). All data were analyzed using standard AMS software SQUIRREL v1.51 and PIKA v1.10 (D. Sueper, University of Colorado-Boulder, Boulder, CO, USA) within Igor Pro 6.2.1 (WaveMetrics, Lake Oswego, OR). Positive matrix factorization (PMF) analyses on the HR-AMS data were performed using the PMF2.exe algorithm (v.4.2) in robust mode (Paatero and Tapper, 1994). The PMF inputs (mass spectral and error matrices) were prepared according to Zhang et al. (2011). The PMF solutions were then evaluated with an Igor Pro-based PMF evaluation tool (PET, v. 2.04) following the method described in Ulbrich et al. (2009) and Zhang et al. (2011). The HR-TOF-AMS collection efficiency (CE) was calculated according to Middlebrook et al. (2011) and averaged $0.48 \pm 0.05$. Concentration of AMS sulfate, nitrate, and ammonium corrected for CE and averaged over Berner impactor sampling periods were in agreement with offline measurements.

The SP-AMS was operated with both the laser and the tungsten vaporizers, alternating the laser on and off every $10 \mathrm{~min}$. The refractory black carbon ( $\mathrm{rBC}$ ) data reported here are obtained in "laser on" mode, which provides measurements of the refractory component of the submicron aerosols, nominally $\mathrm{rBC}$, and of the nonrefractory coating material associated with it. A relative ionization efficiency (RIE) of 0.2 (based on calibration with regal black particles) was applied to the rBC data. A CE of 0.6 was applied to all the SPAMS data (refractory and nonrefractory components) based on comparison of SP-AMS $\mathrm{rBC}$ and BC measured with a multiangle absorption photometer (MAAP). Laser alignment issues did not allow for measurement of aerosol nonrefractory components (i.e. black carbon) before 17 November at 19:30 and between 21 November at 19:00 and 23 November at 16:00 LT. The size distribution data from SP-AMS were not available.

Other colocated measurements included $\mathrm{NH}_{3}$ (Wyers et al., 1993), particle number size distribution (OPC monitor, FAI, Rome, Italy), and daily $\mathrm{PM}_{1}$ mass concentration by beta attenuation measurements (SWAM dual channel monitor, FAI, Rome, Italy).

\subsection{Aerosol optical properties}

Optical measurements of light extinction $\left(b_{\mathrm{ext}}, \mathrm{Mm}^{-1}\right)$ and light absorption $\left(b_{\mathrm{abs}}, \mathrm{Mm}^{-1}\right)$ were respectively measured using a cavity-attenuated phase shift spectrometer particle 
extinction monitor (CAPS PMex) (Kebabian et al., 2007; Massoli et al., 2010) and a particle soot absorption photometer (PSAP) (Bond et al., 1999) valid for the singlewavelength model. The internal flow meter was calibrated with respect to a primary air flow calibrator (Gilian Gilibrator), the spot size was measured with a micrometer, and the aerosol scattering properties $\left(b_{\mathrm{sc}}, \mathrm{Mm}^{-1}\right)$ were determined by an integrating nephelometer (Radiance Research single-wavelength M903) and considered in the absorption corrections according to Bond et al. (1999). PSAP data measured at filter transmissions $<30 \%$ were rejected according to updated indications from PSAP manufacturer. The nominal CAPS data did not require any further corrections, as they were already corrected for gas-phase absorption during an automatic zeroing procedure and for the effects of dilution of the sample flow by the mirrors' purge flow (Massoli et al., 2010). The CAPS $(630 \mathrm{~nm})$ and M903 (539 nm) data were adjusted logarithmically to the PSAP wavelength $(573 \mathrm{~nm})$ according to $\left(b_{\mathrm{x}}\right)_{573}=\left(b_{\mathrm{x}}\right)_{\lambda}(\lambda / 573)^{\alpha}$, where $\left(b_{\mathrm{x}}\right)_{\lambda}$ is the extinction or the scattering coefficient measured at wavelength $\lambda . \alpha$ is the Angström exponent calculated by best fitting the columnar aerosol optical depth within $440 \mathrm{~nm}$ and $870 \mathrm{~nm}$ measured with a POM-02L sun-sky multispectral radiometer (Prede Inc.). The particle single-scattering albedo at $573 \mathrm{~nm}$ (SSA) was calculated as

$\mathrm{SSA}=\left(b_{\mathrm{ext}}-b_{\mathrm{abs}}\right) / b_{\mathrm{ext}}$

or

$\mathrm{SSA}=b_{\mathrm{sc}} / b_{\mathrm{ext}}$.

The CAPS PMex monitors performed measurements with a precision $(2 \sigma)$ of $1 \mathrm{Mm}^{-1}$ at $1 \mathrm{~s}$ time resolution (decreasing to about $0.1 \mathrm{Mm}^{-1}$ for $5 \mathrm{~min}$ integration times). The absolute error in the $b_{\text {ext }}$ coefficient was $5 \%$ at most.

Both HR-TOF-AMSs, the SP-AMS, the CAPS, and the PSAP were connected to the same isokinetic inlet for particle sampling.

\section{Results}

\subsection{Campaign overview}

Figure $2 \mathrm{a}$ shows online nonrefractory $\mathrm{PM}_{1}\left(\mathrm{NR}-\mathrm{PM}_{1}\right)$ together with $\mathrm{PM}_{1}$ time trend and offline chemically reconstructed $\mathrm{PM}_{1.2}$. $\mathrm{PM}_{1}$ was estimated as the sum of $\mathrm{rBC}$ and nonrefractory submicron aerosol components, quantified by SP-AMS and HR-TOF-AMS, respectively. $\mathrm{PM}_{1.2}$ represents the sum of sulfate, nitrate, ammonium, water-soluble organic mass (WSOM), and water-insoluble carbon mass (WICM) from the analysis of the first three stages of size-segregated Berner impactor. WSOM was calculated from the watersoluble organic carbon, using an $\mathrm{OM}$ to $\mathrm{OC}$ ratio of 1.6 , in agreement with elemental analysis of high-resolution AMS data. WICM was derived from water-insoluble carbon concentration using a conversion factor of 1.1. The concen- trations of AMS sulfate, nitrate, and ammonium corrected for $\mathrm{CE}$ and averaged over Berner impactor sampling periods were in agreement with offline measurements. The good agreement between online and offline measurements indicates that sampling artifacts of submicron particles were negligible and confirmed that the $\mathrm{CE}$ correction of the online AMS data was accurate.

Total $\mathrm{PM}_{1}$ concentration, whose average was $22 \pm$ $15 \mu \mathrm{g} \mathrm{m}^{-3}$ over the entire campaign, varied with fog, with higher $\mathrm{PM}_{1}$ values when fog was not present. $\mathrm{PM}_{1}$ concentration averaged $32 \pm 14 \mathrm{~g} \mathrm{~m}^{-3}$ under clear conditions $\left(\mathrm{LWC}<0.08 \mathrm{~g} \mathrm{~m}^{-3}\right.$ ) and $10 \pm 6 \mu \mathrm{g} \mathrm{m}^{-3}$ in fog (LWC > $0.08 \mathrm{~g} \mathrm{~m}^{-3}$ ), corresponding to an average decrease of $60 \%$ in mass during fog events. Concentration reduction occurred rapidly in time. Events characterized by a rapid increase in LWC were associated with a decrease in $\mathrm{PM}_{1}$ in less than 15 min (Fig. 2a).

$\mathrm{PM}_{1}$ concentration in the range $10-30 \mu \mathrm{g} \mathrm{m}^{-3}$ was in agreement with previous measurements performed at the same site during winter 2008 (Carbone et al., 2010). These values, especially for out-of-fog conditions, are higher than the average $\mathrm{PM}_{2.5}$ reported for several rural background and urban background sites (Putaud et al., 2010), and higher than the EU target limit of $25 \mathrm{\mu g} \mathrm{m}^{-3}$ set by the EU air quality directive for $\mathrm{PM}_{2.5}(\mathrm{EU} / 50 / 2008)$.

Figure $2 b$ shows the time trend of the submicron chemical components as measured by the HR-TOF-AMS. Submicron mass was dominated by organics and ammonium nitrate, as also observed in previous campaigns (Carbone et al., 2010). Average mass fraction was $54 \pm 12 \%$ for organic matter, $27 \pm$ $10 \%$ for nitrate, $10 \pm 3 \%$ for ammonium, and $6 \pm 3 \%$ for sulfate.

Previous work has shown that the OA loadings in the rural Po Valley during fall are usually dominated by traffic emissions and wood burning for residential heating purposes (Gilardoni et al., 2011). To identify OA main sources during fall 2011 in San Pietro Capofiume, PMF analyses were performed on the organic mass spectral matrices. For this database, we chose a four-factor solution with rotational forcing parameter $f_{\text {Peak }}=0\left(Q / Q_{\text {exp }}=4\right)$, yielding a hydrocarbon-like OA (HOA) component, a low-volatility oxygenated OA (LV-OOA) component, and two biomass burning OA (BBOA) components, which were recombined into one BBOA factor. A detailed summary of key diagnostic plots of the PMF results and a discussion of the factor solution choices are reported in Supplement (Figs. 1S, 2S, 3S, and $4 \mathrm{~S}$ and related text). Figure 3 shows HOA, LV-OOA and BBOA from top to bottom. During the campaign the HOA had an average mass of $2 \mu \mathrm{g} \mathrm{m}^{-3}$, whereas the BBOA was low $\left(0.5 \mu \mathrm{g} \mathrm{m}^{-3}\right)$ until 22 November and then increased significantly during the rest of the campaign due to a decrease of ambient temperature and probably increase in emissions from wood burning for residential heating. After 22 November, BBOA averaged $2.5 \mu \mathrm{g} \mathrm{m}^{-3}$, except for a $8 \mathrm{~h}$ event occurring between 28 and 29 November, when $16 \mu \mathrm{g} \mathrm{m}^{-3}$ of 


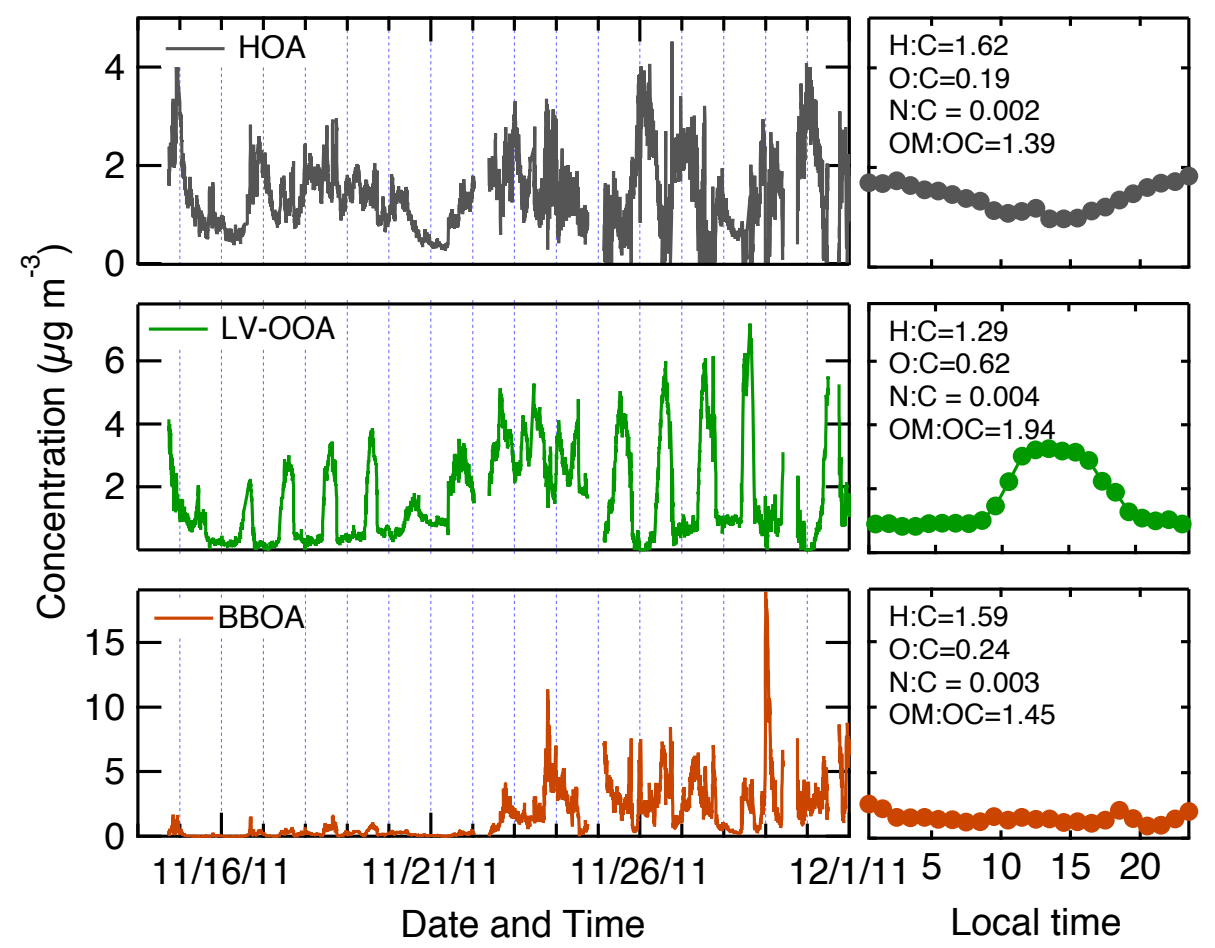

Figure 3. Time series of HOA (grey), LV-OOA (green), and BBOA (red) and their diurnal time trend.

BBOA was measured. The LV-OOA time series show a more regular pattern through the 2 -week time period, with loadings ranging from $1 \mu \mathrm{g} \mathrm{m}^{-3}$ at night to $5 \mu \mathrm{g} \mathrm{m}^{-3}$ during the day, thereby following a time trend opposite to that of LWC. In fact the highest concentrations of LV-OOA were observed when LWC was lower, i.e. out of fog. Interpretation of PMF factors is clearer when looking at the diurnal profiles of the three factors (Fig. 3), which show a strong diurnal cycle in LV-OOA (peaking between 12:00 and 17:00 LT) and a mild opposite trend in the HOA factor (slightly lower during daytime than at nighttime). The BBOA diurnal trend is instead mostly flat due to efficient fog removal during nighttime, when higher emissions are expected.

Table 1 summarizes the Pearson correlation coefficients $(r)$ between the three PMF factors and several gas-phase and particle tracers. HOA correlates best with $\mathrm{NO}(r=0.62)$ whereas BBOA correlates with $\mathrm{rBC}(r=0.75)$ and biomass burning tracers, i.e. levoglucosan $(r=0.71)$ and potassium $(r=0.80)$. The LV-OOA factor correlates strongly with secondary inorganic ions, i.e. sulfate and nitrate $(r=0.85$ and $r=0.90$, respectively), and has a stronger correlation than BBOA with more oxidized species as oxalic acid $(r=0.96)$. The LV-OOA correlates also with amines, calculated as the sum of monomethyl, dimethyl, and trimethyl amines from offline HNMR analysis $(r=0.71)$.

The elemental composition $(\mathrm{H} / \mathrm{C}, \mathrm{O} / \mathrm{C}, \mathrm{N} / \mathrm{C})$ and the $\mathrm{OM} / \mathrm{OC}$ calculated using the standard AMS data analysis code (Aiken et al., 2007) are also reported in Fig. 3. The av-
Table 1. Correlation coefficients $r$ of the PMF factors with the main external gas-phase and aerosol tracers measured at SPC during the campaign. The values in bold denote the highest correlations for each factor. The asterisks indicate data from filter analysis.

\begin{tabular}{lccc}
\hline Species & HOA & BBOA & LV-OOA \\
\hline BC & 0.35 & $\mathbf{0 . 7 5}$ & 0.30 \\
$\mathrm{NO}$ & $\mathbf{0 . 6 2}$ & 0.34 & -0.34 \\
$\mathrm{O}_{3}$ & 0.36 & -0.06 & 0.50 \\
Sulfate & -0.03 & 0.20 & $\mathbf{0 . 8 5}$ \\
Nitrate & -0.05 & 0.25 & $\mathbf{0 . 9 0}$ \\
Chloride & 0.05 & 0.55 & 0.48 \\
Levoglucosan* & 0.33 & $\mathbf{0 . 7 1}$ & 0.14 \\
K $^{+*}$ & -0.20 & $\mathbf{0 . 8 0}$ & 0.49 \\
Oxalic acid* & -0.47 & 0.61 & $\mathbf{0 . 9 6}$ \\
\hline
\end{tabular}

erage $\mathrm{O} / \mathrm{C}$ ratio calculated for the HOA component (0.19) is slightly higher than what was found for HOA factors of HR-TOF-AMS spectra in urban areas ( 0.1 or less). However, a very similar HOA mass spectrum (with a fairly large $\mathrm{CO}_{2}^{+}$ signal at $m / z=44$ ) was measured during the 2008 spring campaign at the same location (Saarikoski et al., 2012). The relatively large oxygenation of this HOA is likely due to the fact that the SPC station is a rural area away from direct urban and fresher (less oxidized) emissions. The average $\mathrm{H} / \mathrm{C}$ and $\mathrm{O} / \mathrm{C}$ values for the BBOA component are 1.59 and 0.24 , respectively, consistent with literature BBOA mass spectra (Mohr et al., 2012; Saarikoski et al., 2012). The average H / C 
Table 2. Mass scavenging efficiency $(\eta)$ of the different chemical species, scavenging of particle larger than $700 \mathrm{~nm}(N>700 \mathrm{~nm})$, and meteorological parameters characteristic of each fog event.

\begin{tabular}{c|cccccccc|ccc}
\hline & \multicolumn{10}{|c}{$\eta$} & \multicolumn{3}{|c}{ Meteorological parameters } \\
\hline Event & $\mathrm{BC}$ & $\mathrm{Chl}$ & $\mathrm{NH}_{4}$ & $\mathrm{NO}_{3}$ & Org & $\mathrm{SO}_{4}$ & Org oxygen & $N>700 \mathrm{~nm}$ & LWC $\left(\mathrm{g} \mathrm{m}^{-3}\right)$ & $T$ drop $\left({ }^{\circ} \mathrm{C}\right)$ & ${\mathrm{WS}\left(\mathrm{m} \mathrm{s}^{-1}\right)}^{-1}$ \\
\hline 1 & & 0.21 & 0.52 & 0.56 & 0.41 & 0.58 & 0.51 & 0.40 & 0.14 & 0.0 & 2.0 \\
2 & & 0.69 & 0.73 & 0.74 & 0.45 & 0.76 & 0.60 & 0.76 & 0.14 & 3.1 & 0.9 \\
3 & & 0.71 & 0.76 & 0.78 & 0.57 & 0.73 & 0.65 & 0.85 & 0.18 & 5.9 & 1.5 \\
4 & 0.57 & 0.81 & 0.78 & 0.79 & 0.63 & 0.81 & 0.73 & 0.86 & 0.20 & 2.9 & 1.7 \\
5 & 0.56 & 0.90 & 0.82 & 0.85 & 0.61 & 0.72 & 0.69 & 0.68 & 0.13 & 1.8 & 1.0 \\
6 & 0.40 & 0.69 & 0.75 & 0.75 & 0.54 & 0.70 & 0.66 & 0.71 & 0.13 & 3.1 & 1.5 \\
7 & & 0.04 & 0.42 & 0.47 & 0.22 & 0.12 & 0.29 & 0.55 & 0.16 & 0.5 & 1.9 \\
8 & 0.53 & 0.71 & 0.77 & 0.79 & 0.61 & 0.78 & 0.70 & 0.83 & 0.18 & 3.6 & 1.1 \\
9 & & 0.45 & 0.74 & 0.77 & 0.54 & 0.57 & 0.62 & 0.84 & 0.21 & 4.1 & 1.8 \\
10 & 0.42 & 0.81 & 0.84 & 0.85 & 0.56 & 0.71 & 0.75 & 0.84 & 0.19 & 4.1 & 1.2 \\
11 & & 0.49 & 0.46 & 0.48 & 0.37 & 0.31 & 0.42 & 0.70 & 0.20 & 1.0 & 1.9 \\
12 & 0.31 & 0.66 & 0.73 & 0.74 & 0.52 & 0.66 & 0.62 & 0.71 & 0.14 & 4.4 & 1.3 \\
13 & 0.33 & 0.47 & 0.70 & 0.74 & 0.49 & 0.50 & 0.57 & 0.65 & 0.11 & 3.9 & 1.1 \\
14 & & 0.54 & 0.56 & 0.57 & 0.51 & 0.50 & 0.55 & - & 0.21 & -1.5 & 1.7 \\
\hline
\end{tabular}

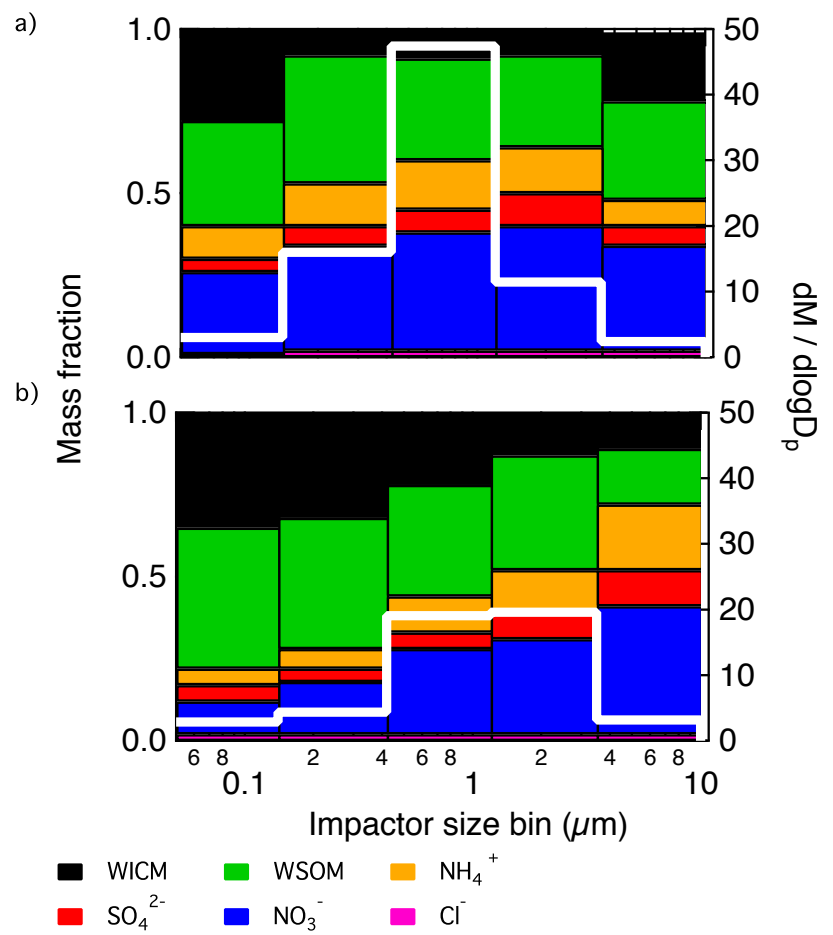

Figure 4. Size-resolved average aerosol composition and mass size distribution (white line) during daytime (09:00-18:00 LT, a) and during nighttime (18:00-09:00 LT, b).

and $\mathrm{O} / \mathrm{C}$ values for the LV-OOA component are 1.29 and 0.62 , respectively, in agreement with values reported by $\mathrm{Ng}$ et al. (2010) for urban downwind and rural areas.

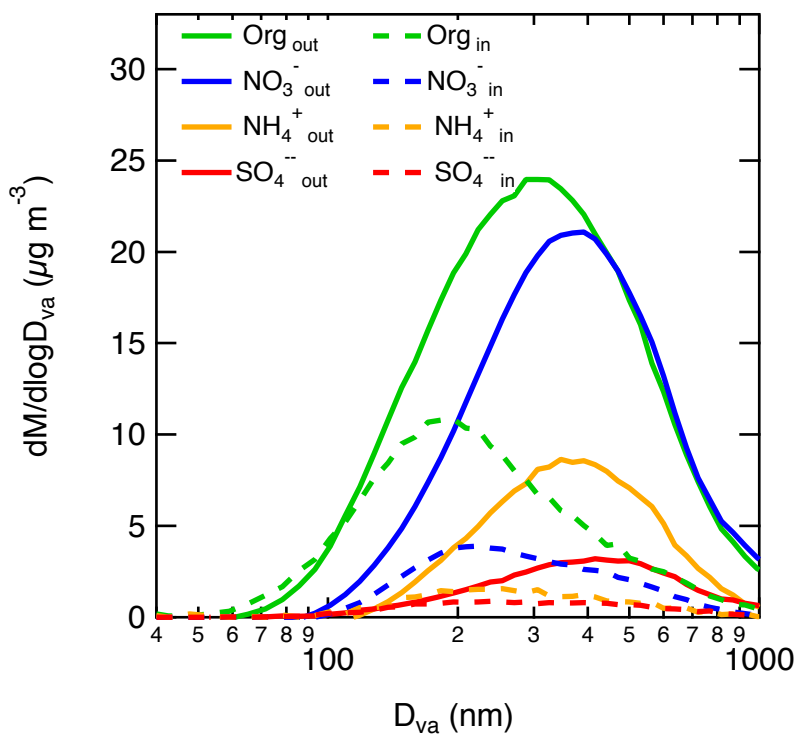

Figure 5. Mass size distribution of major constituents of submicron particle out of fog (straight line) and in fog (dotted line) averaged over the entire campaign.

\subsection{Fog scavenging}

Figure 4 compares the size-resolved reconstructed mass and particle composition in the range $50 \mathrm{~nm}-10 \mu \mathrm{m}$ during night and day. Data are obtained from offline analysis of Berner impactor samples, collected during day- and nighttime. Most of the nighttime collection periods overlapped with fog events, so nighttime data are representative of in-fog conditions, while daytime average composition represents out-offog conditions. 
Aerosol mass concentration of particles smaller than $140 \mathrm{~nm}$ and larger than $3.5 \mu \mathrm{m}$ accounted for less than $10 \%$ of aerosol loading, and was not affected by fog scavenging. Particles with aerodynamic diameter between $140 \mathrm{~nm}$ and $1.2 \mu \mathrm{m}$ were those mostly affected by the presence of fog. Fog scavenging removed 50 to $70 \%$ of their mass. Occasionally mass concentration of particles larger than $3.5 \mu \mathrm{m}$ slightly increased during fog, likely due to the collection of fog droplets on the upper impactor stages, as also observed during previous campaigns (Fuzzi et al., 1992).

Comparison of size-resolved composition shows that fog scavenging removes water-soluble inorganic species more efficiently than organic matter, increasing the contribution of carbonaceous material up to $80-90 \%$ in interstitial particles. In addition, scavenging changes the properties of this carbonaceous fraction increasing the WICM to WSOM ratio in submicron particles from $0.2-0.3$ before fog to $0.6-0.8$ during fog. The enrichment of OA in insoluble species is consistent with the results reported by Facchini et al. (1999a) based on fog and interstitial aerosol chemical characterization.

The effect of scavenging on the size and chemical composition of the submicron aerosol was further analyzed at higher resolution using the online pToF measurements from the HR-TOF-AMS (Fig. 5). The figure shows that the mean mode diameter shifted from $300-400 \mathrm{~nm}$ to $200-250 \mathrm{~nm} D_{\text {va }}$ when going from out-of-fog to in-fog conditions. The largest change in mass was observed for nitrate, followed by organics. It is also interesting to see that organic and inorganic components were partially internally mixed (organic modes peaking at slightly smaller $D_{\text {va }}$ ) both in fog and out of fog.

Table 2 reports mass scavenging efficiency of major chemical components of submicron particles. Based on the HRTOF-AMS measurements, mass scavenging efficiency $(\eta)$ was calculated by comparing the concentration of each chemical species before fog formation and right after fog formation according to Noone et al. (1992).

$\eta=1-\frac{[X]_{\text {interstitial }}}{[X]_{\text {before fog }}}$

The variability of scavenging efficiency among the different chemical species can be explained by their hygroscopicity $(\kappa)$. Nitrate and ammonium showed the highest mass scavenging efficiencies, on average 71 and $68 \%$, respectively. Black carbon, the most hydrophobic component, was the species least efficiently scavenged (39\% on average). OA showed the largest variability, with $\eta$ ranging between 20 and $60 \%$, in agreement with previous observations (Collett et al., 2008). Collett et al. (2008) observed a slight correlation between OA scavenging and LWC. During the Po Valley experiment, the variability of $\eta$ observed among the different fog events could not be explained by the variability of LWC. In fact, the correlation coefficient $\left(r^{2}\right)$ of organic $\eta$ and LWC was 0.02 , indicating that LWC explained only $2 \%$ of the organic scavenging variability.
The scavenging efficiency of sulfate was slightly lower than the one of nitrate $(61 \%)$. The difference between sulfate and nitrate scavenging observed during events 5, 7, 9, $10,11,12$, and 13 could be explained by fog processing, i.e., in situ formation of sulfate though oxidation of $\mathrm{SO}_{2}$ in the aqueous phase. Fog processing would contribute to sulfate formation, compensating in part for the removal associated with scavenging. Fog processing plays a major role in secondary organic and inorganic aerosol formation (Kaul et al., 2011; Sun et al., 2013), and its effects on aerosol composition and properties need further investigation.

Fog scavenging of different aerosol chemical components was previously investigated in the Po Valley fog system by Hallberg et al. (1992) and by Facchini et al. (1999a). The average scavenging efficiencies reported by Hallberg et al. (1992) for sulfate $(18 \%)$ and EC $(6 \%)$ were significantly lower than those measured during the present study. On the other hand, sulfate scavenging observed at the same site during a different experiment was $60 \%$ (Facchini et al., 1999a) and agrees well with the values here reported. The scavenging efficiencies of ammonium and nitrate measured during the fall 2011 experiment are comparable to the upper bound of the variability range reported by Facchini et al. (1999a) (0.3-0.7). In addition, Facchini et al. (1999a) observed that scavenging of OA was lower compared to that of inorganic species; nevertheless, scavenging of WSOM was similar to that of nitrate and ammonium. The results of the present study confirm those observations.

Previous scavenging studies lack information about the size distribution of different chemical components, which, together with hygroscopicity, might have a significant role in determining the overall scavenging variability. Scavenging follows particle activation by water uptake, and based on Köhler theory, activation of particles larger than $300-400 \mathrm{~nm}$ is more likely to occur than for smaller particles, especially at low supersaturation typical of fog events. Ammonium and nitrate mass size distribution peaked around $400-500 \mathrm{~nm} D_{\text {va }}$, organic distribution had a maximum above $250 \mathrm{~nm} D_{\text {va }}$, and $\mathrm{rBC}$, whose size distribution was not measured, is expected to peak around $100 \mathrm{~nm} D_{\mathrm{va}}$ ("primary soot" mode); a much less intense rBC mode can be sometimes present in the accumulation region at $400-450 \mathrm{~nm} D_{\mathrm{va}}$ ("aged soot" mode) for aged aerosol (Onasch et al., 2012; Massoli et al., 2012).

Figure 6 shows the trends in SSA obtained from combining CAPS extinction with PSAP absorption coefficients, and CAPS extinction with nephelometer scattering coefficients, according to Eq. (1). Good agreement between the two SSA trends was observed, with an average error below $2 \%$. The discrepancy observed between 21 and 23 November is likely due to the uncertainty of $b_{\mathrm{abs}}$, which was often below $0.05 \mathrm{Mm}^{-1}$ during these days. The SSA shows a diurnal trend with high SSA values during the day without fog (reaching 0.9 during midday) and low SSA values at night in fog, with SSA values as low as 0.7. This is consistent with the time trends shown in Figs. 2 and 3 and with the fact 


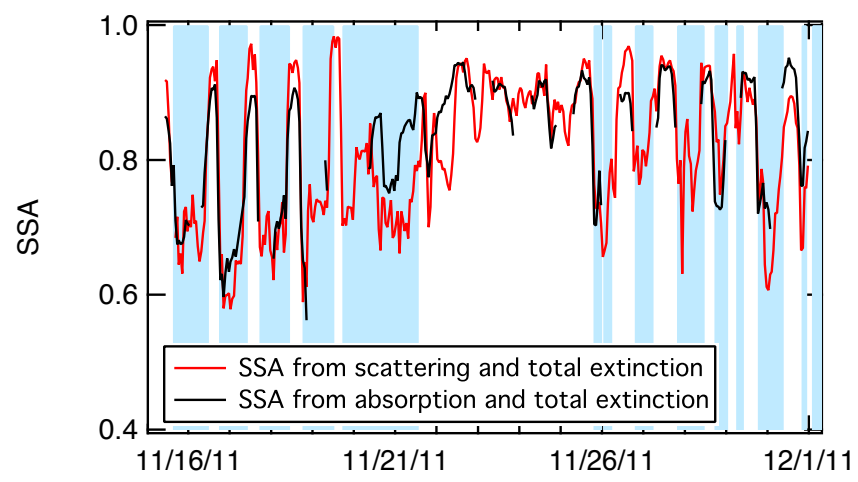

Figure 6. Time trend of SSA at $573 \mathrm{~nm}$ calculated from absorption and total extinction coefficients (black) and from scattering and total extinction coefficients (red). Light-blue shadowed areas indicate fog periods.

that fog scavenging removed water-soluble species (hygroscopic and light-scattering) and left behind particles enriched in carbonaceous material (less hygroscopic and more lightabsorbing). The smoother diurnal trend in SSA observed between 21 and 25 November corresponds to times when the fog events were less pronounced, LWC was low, and temperature was varying less (cf. Figs. 1 and 2).

\subsection{Effect of OA local sources on scavenging uncertainty}

Local emissions that add to the preexisting aerosol in concomitance with the beginning of a fog formation event could lead to the underestimation of fog scavenging. For the OA, sources include a regional component (LV-OOA), a local component (BBOA), and a third component (HOA) that has both local and regional sources. The concentration of HOA and BBOA factors is expected to increase during the evening hours, as confirmed by diurnal time trend observed when fog was not present (22 and 23 November) and consistent with results reported by Saarikoski et al. (2012) for the same season. These local sources might lead to an underestimation of organic scavenging efficiency during evening fogs. Assuming that the 22 and 23 November could be used as a reference period to identify the diurnal behavior of HOA and BBOA, we can use these days to obtain a rough estimate of the scavenging underestimation. The diurnal trend of $\mathrm{HOA}$ and BBOA factors for the reference period is reported in Fig 5S. The trend of HOA between 16:00 and 19:00 LT during days with no fog shows an increase of about $0.4 \mu \mathrm{g} \mathrm{m}^{-3} \mathrm{~h}^{-1}$, while during days with fog the increase is about $0.1 \mu \mathrm{g} \mathrm{m}^{-3} \mathrm{~h}^{-1}$. The difference corresponds to a removal rate of $0.3 \mu \mathrm{g} \mathrm{m}^{-3} \mathrm{~h}^{-1}$. Similarly, the average diurnal trend suggests that the removal rate of BBOA factor is about $1 \mu \mathrm{g} \mathrm{m}^{-3} \mathrm{~h}^{-1}$. Considering that the average organic concentration after fog formation in the evening events is about $7 \mu \mathrm{g} \mathrm{m}^{-3}$ and that the integration time used to calculate scavenging efficiency is $2 \mathrm{~h}$, the uncertainty on organic concentration associated with neglecting HOA and BBOA local sources would range between $8 \%$ (during the first period, when BBOA contribution was negligible) and $36 \%$ (during the second period, when BBOA mass fraction was more significant). Taking into account this uncertainty, the average scavenging efficiency of organics would increase from 50 to $58 \%$, which is within the variability of the data.

\section{Discussion}

The objective of this section is to investigate the effect of particle composition and microphysical properties on nucleation scavenging. Equation (2) assumes that the same air parcel is sampled before and right after fog formation; the intrusion of fresh air masses and the contribution of aerosol local sources would change the composition of the aerosol, making nucleation scavenging calculation inaccurate. For this reason, (i) we calculated scavenging efficiency based on observations over a short time interval $(30 \mathrm{~min}$ before and after fog formation) and (ii) we excluded fog events associated with fog transport or intrusion. The time interval of $30 \mathrm{~min}$ was chosen as the shortest interval that allowed an accurate pToF measurement. Intrusion events were identified based on the analysis of meteorological parameters (Table 2).

Fog events 2, 3, 4, 5, 6, 8, 9, 10, 12, and 13 were characterized by temperature decrease, stagnant conditions (i.e. wind speed below $2 \mathrm{~m} \mathrm{~s}^{-1}$ ), and almost complete scavenging of particles above $700 \mathrm{~nm}$. In agreement with previous observations in the Po Valley, we classified these events as radiation fog (Noone et al., 1992; Wobrock et al., 1992; Whiteaker et al., 2002). Thus, changes in aerosol concentration should be attributed mainly to nucleation scavenging. However, we identified those events characterized by no or very small temperature variation and higher wind speed as fog transport/intrusion events $(1,7,11$, and 14). The scavenging of particles larger than $700 \mathrm{~nm}$ was consistently below $70 \%$ (Table 2).

Fog events characterized by intrusion were also characterized by lower scavenging efficiencies. During these events, the prevailing wind direction was from north, northwest, and west, where major traffic roads and urban areas are located. It is likely that transport of pollutants to the measurement site was responsible for the apparently lower scavenging efficiency. Removing these intrusion events from the list of investigated fog events reduces the variability of observed scavenging. The standard deviation of the average scavenging efficiency of nitrate, for example, goes from $18 \%$ when all events are taken into account to $6 \%$ when only radiation fog events are considered. The standard deviation of organic average scavenging efficiency is halved (from 22 to $11 \%$ ).

To study the effect of chemical composition and particle size on scavenging, we investigated scavenging efficiency size distribution for the main submicron chemical 

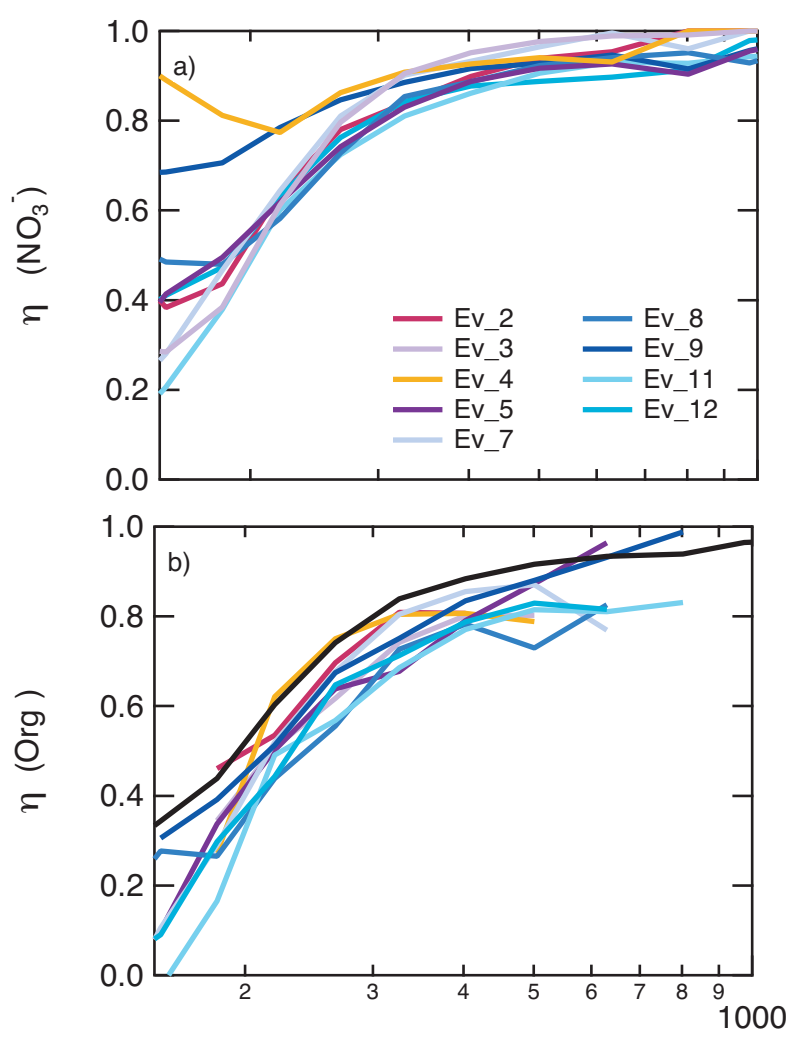

Dva $(\mathrm{nm})$

Figure 7. Mass scavenging efficiency $(\eta)$ size distribution of nitrate (a) and organics (b) for each fog event; the black line in (b) corresponds to average nitrate scavenging efficiency. $D_{\mathrm{va}}$ is vacuum aerodynamic diameter.

components (nitrate, as representative of inorganic aerosol, and organics) only during radiation fog events.

\subsection{Nitrate scavenging}

Figure 7a reports the size distribution of $\eta$ for nitrate mass concentration corresponding to the different radiation fog events. $\eta$ is calculated comparing nitrate size distribution from $\mathrm{pToF}$ measurements averaged over $30 \mathrm{~min}$ before fog formation and over $30 \mathrm{~min}$ after fog formation. Except for events 4 and 9 , all fog events showed similar variation of $\eta$, with values of about 0.5 at $200 \mathrm{~nm} D_{\text {va }}$, corresponding to a geometric diameter of $133 \mathrm{~nm}$ (assuming spherical particles with density $1.5 \mathrm{~g} \mathrm{~cm}^{-3}$ ).

The largest variation of $\eta$ was observed below $200 \mathrm{~nm}$ (from 20 to $80 \%$ ), while above $400 \mathrm{~nm}, \eta$ ranged between 90 and $100 \%$ for all the events. We explained $\eta$ variability based on particle chemical composition, particularly by taking into account the contribution of organic matter to particle mass. While ammonium nitrate particles are hydrophilic, organic particulate matter is expected to be more hydrophobic (Petters and Kreidenweis, 2008). Figure 8a shows that $\eta$ of nitrate was higher for larger particles and smaller for smaller particles. Within the same size range, $\eta$ decreased with increasing organic mass fraction, i.e. increasing the contribution of a more hydrophobic component. Similarly, Fig. 8b reports $\eta$ variability as a function of $\kappa$ (Petters and Kreidenweis, 2008). $\kappa$ is a measure of particle hygroscopicity, and was calculated assuming that aerosol was internally mixed according to

$\kappa=\sum_{i} \epsilon_{i} \kappa_{i}$

$\epsilon_{i}$ and $\kappa_{i}$ are the volume fraction and the hygroscopicity of the single component $i$, respectively. To calculate the volume fractions, the following densities were used: $1.72 \mathrm{~g} \mathrm{~cm}^{-3}$ for nitrate, $1.78 \mathrm{~g} \mathrm{~cm}^{-3}$ for sulfate, $1.75 \mathrm{~g} \mathrm{~cm}^{-3}$ for ammonium, $1.4 \mathrm{~g} \mathrm{~cm}^{-3}$ for chloride, and $1.27 \mathrm{~g} \mathrm{~cm}^{-3}$ for organics (Duplissy et al., 2011). $\kappa_{i}$ was assumed equal to 0.7 for nitrate sulfate, and ammonium; 1.3 for chloride; and 0.15 for organics (Petters and Kreidenweis, 2007; Jimenez et al., 2009; Gunthe et al., 2009; Chang et al., 2010).

Within each size range, more hygroscopic particles were more efficiently scavenged. The hygroscopicity had a larger effect on $\eta$ of smaller particles, while for particles larger than $300 \mathrm{~nm}$, hygroscopicity, and thus chemical composition, affected scavenging weakly. The correlation coefficients $r^{2}$ corresponding to particles below $200 \mathrm{~nm} D_{\text {va }}(0.51)$ indicates that hygroscopicity explained $50 \%$ of nitrate scavenging variability.

\subsection{Organic scavenging}

Figure $7 \mathrm{~b}$ reports the size distribution of $\eta$ for organic mass concentration. $\eta$ curves for organics are slightly lower than nitrate curves (average nitrate is reported in black) and showed a larger variability. $\eta$ for organics reached 0.5 around $250 \mathrm{~nm} D_{\text {va }}$, and increased with increasing diameter, reaching values above 0.9 only for particles larger than $600 \mathrm{~nm}$ $D_{\text {va }}$. Event 2 is not reported because the organic loading was too low to allow for an accurate analysis of scavenging size trend.

The similarity between organic and nitrate $\eta$ curves supports the hypothesis that most of the organic mass was internally mixed with nitrate, as also suggested by the similar size distribution of pToF curves (Fig. 5). In fact, if organics were not internally mixed with water-soluble species, their scavenging below $1 \mu \mathrm{m}$ at very low supersaturation observed in fog would be close to zero (Petters and Kreidenweis, 2008). It follows that the largest part of organic mass scavenged in submicron particles was internally mixed with nitrate. Based on this conclusion, and assuming that all the scavenged organic aerosol was internally mixed with the scavenged nitrate, we can estimate the organic mass fraction internally mixed with nitrate to be equal to the organic scavenging efficiency normalized over nitrate scavenging efficiency in each size bin. According to this, 50 to $90 \%$ of organic 


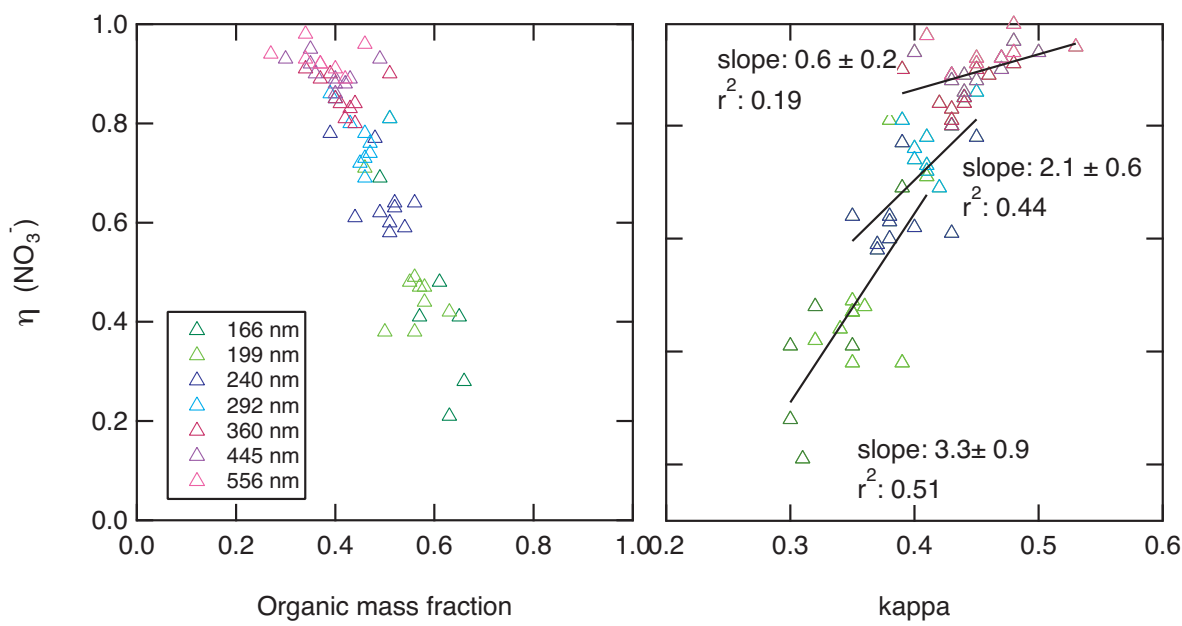

Figure 8. Size-segregated scavenging efficiency of nitrate as a function of organic mass fraction (a) and $\kappa(\mathbf{b})$; markers are color-coded as a function of particle diameter $\left(D_{\mathrm{va}}\right)$.

mass resulted internally mixed with nitrate in the range 150 $700 \mathrm{~nm}\left(D_{\mathrm{va}}\right)$. The lower mixing ratios were observed for particles smaller than $200 \mathrm{~nm} D_{\text {va }}$, on average $35 \%$, in agreement with values expected for primary and less processed particles.

The correlation of size-segregated scavenging efficiency of nitrate and organics suggests that OA scavenging is controlled mainly by mixing with more hydrophilic species, at least for larger particles (about $350 \mathrm{~nm} D_{\mathrm{va}}$ ). This result does not exclude that OA scavenging variability could be affected by OA properties. With this in mind, the OA composition was further investigated by FTIR spectroscopy.

To verify the consistency between AMS and FTIR results, we compared the oxygen to carbon ratio $(\mathrm{O} / \mathrm{C})$, estimated by means of elemental analysis of AMS data (Aiken et al., 2008) to the one calculated via the contribution of oxygenated and nonoxygenated functional groups quantified by FTIR spectroscopy. Among oxygenated groups, FTIR identified organonitrates, which are not included in the organic oxygen budget in the AMS analysis. Thus, we compared the $\mathrm{O} / \mathrm{C}$ ratio from AMS to the FTIR ratio calculated without the contribution of organonitrates. Figure 9 shows that the agreement between the two techniques was satisfactory (generally within $10 \%$ ) for samples characterized by a shorter collection period (below $15 \mathrm{~h}$ ) (Maria et al., 2003). In the following paragraphs we limit our considerations to those samples characterized by a collection period shorter than $15 \mathrm{~h}$.

Functional group analysis by FTIR showed that organic mass was mainly composed of alkylic, carboxylic, and hydroxyl groups, representing on average 44,28 , and $22 \%$ of organic mass, respectively. Organic nitrogen species, i.e. amines and organonitrates, accounted for a small fraction of the OA loading.

It is worth noting that the organonitrate functional group represents a small fraction of organic mass; nevertheless its

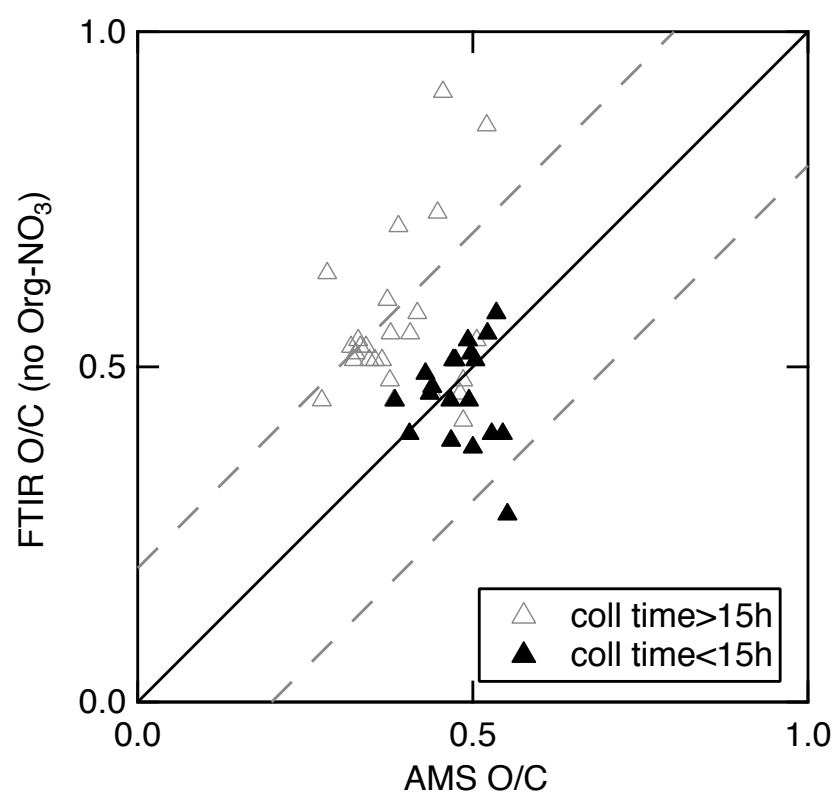

Figure 9. Comparison of oxygen to carbon ratio from analysis of organic aerosol by FTIR and AMS. For the comparison, FTIR ratio is calculated ignoring the contribution of organonitrate. Black triangles are samples with collection time below $15 \mathrm{~h}$

presence could affect the $\mathrm{O} / \mathrm{C}$ ratio. For example, when organonitrates comprised $6 \%$ of organic mass, the $\mathrm{O} / \mathrm{C}$ ratio was $14 \%$ higher than the $\mathrm{O} / \mathrm{C}$ measured by AMS or calculated by FTIR functional group excluding nitrate contribution.

Table 3 reports the scavenging efficiency of organic aerosol for four fog events when organic functional group composition from FTIR was available right before fog formation. The scavenging efficiency of organic aerosol was slightly correlated with the average $\mathrm{O} / \mathrm{C}$ ratio obtained from 
Table 3. Comparison of scavenging efficiency of organic aerosol and organic oxygen with elemental analysis and organic functional group data.

\begin{tabular}{lcccc}
\hline Date & $\begin{array}{c}\text { 18 Nov 11 } \\
\text { Event \# }\end{array}$ & $\begin{array}{c}28 \text { Nov } 11 \\
10\end{array}$ & $\begin{array}{c}\text { 29 Nov } 11 \\
12\end{array}$ & $\begin{array}{c}30 \text { Nov } 11 \\
13\end{array}$ \\
\hline$\eta$ organic & 0.63 & 0.56 & 0.52 & 0.49 \\
$\eta$ org oxygen & 0.73 & 0.75 & 0.62 & 0.57 \\
O C & 0.52 & 0.50 & 0.47 & 0.40 \\
$\mathrm{COOH} / \mathrm{OH}$ & 2.00 & 0.77 & 0.80 & 0.79 \\
\hline
\end{tabular}

the FTIR data. Samples characterized by the highest $\mathrm{O} / \mathrm{C}$ ratio were also associated with the highest $\mathrm{OA}$ scavenging (18 and 28 November). The higher scavenging of more oxygenated aerosol is also confirmed by higher scavenging efficiency of the organic oxygen compared to the total OA (Table 2). This result can be attributed to the highest polarity, and thus hygroscopicity, of oxidized organic aerosols and to a more efficient mixing of oxidized/aged organics with secondary inorganic aerosol, which is more hydrophilic.

We speculate that the effect of mixing might be more relevant than the effect of polarity and hygroscopicity by itself. If oxidized organics were removed by fog more efficiently than less oxidized species only because of being more hygroscopic, then the scavenging of organic oxygen should have been constant or only slightly variable, as observed, for example, for nitrate. The fact that organic oxygen scavenging efficiency varied by 18 percentage points during radiation fog events indicates that a different effect is controlling its scavenging, more likely efficiency of mixing with highly hygroscopic species, such as ammonium nitrate.

This conclusion is further supported by the analysis of the main oxygenated organic functional groups. Table 3 reports the molar ratio of the carboxylic $(\mathrm{COOH})$ to the hydroxyl $(\mathrm{OH})$ group. For a molecule with a defined number of carbon atoms, the $\mathrm{COOH}$ and $\mathrm{OH}$ groups are expected to affect its solubility in different ways. In fact, the $\mathrm{COOH}$ group has a dipole moment larger than the one of an $\mathrm{OH}$ group, and thus the $\mathrm{COOH}$ group would increase its solubility more than a $\mathrm{OH}$ group. The fog events of 28, 29, and 30 November showed a very similar $\mathrm{COOH}$ to $\mathrm{OH}$ ratio, indicating that the relative contribution of oxygenated functional groups was similar. Nevertheless, organic oxygen scavenging efficiency varied from 57 to $75 \%$. The limited number of available measurements and the lack of information on the average OA molecular weight and carbon chain length do not allow us to understand the effect of the chemical nature of organic oxygen on the variability of organic scavenging during the Po Valley experiment.

\subsection{Scavenging closure}

We verified the closure of nitrate and organic scavenging efficiency during radiation fog using a simple model based on size-segregated chemical composition. For each fog event the efficiency of nitrate scavenging was modeled according to the following equation:

$\eta_{\mathrm{NO}_{3}} \bmod =\frac{\Sigma_{i}\left[\mathrm{NO}_{3}^{-}\right]_{i} \eta_{i} \Delta \log D_{\mathrm{va}_{i}} / \text { lens }_{i}}{\Sigma_{i}\left[\mathrm{NO}_{3}^{-}\right]_{i} \Delta \log D_{\mathrm{va}_{i}} / \text { lens }_{i}}$,

where $\left[\mathrm{NO}_{3}^{-}\right]_{i}$ is the concentration of nitrate before fog formation in size bin $i$ (as $d \mathrm{M} / d \log D_{\text {va }}$ ) and lens $s_{i}$ is the transmission efficiency of the aerodynamic lens of the HR-TOFAMS for size bin $i$. Values of nitrate concentration below detection limit were replaced by half of the detection limit. $\eta_{i}$ is the scavenging efficiency of nitrate in size bin $i$. The dependency of $\eta_{i}$ on $\kappa$ varies with particle size $\left(D_{v a}\right)$, as shown in Sect. 4.1. Thus, we estimated $\eta_{i}$ from $\kappa$ and $D_{\mathrm{va}}$ based on the equations corresponding to the linear fits reported in Fig. 8b:

$\eta_{i}= \begin{cases}0 & \text { if } D_{\mathrm{va}}<166 \mathrm{~nm} \\ 3.3 \cdot k-0.7 & \text { if } 166 \mathrm{~nm} \leq D_{\mathrm{va}}<240 \mathrm{~nm} \\ 2.1 \cdot k-0.2 & \text { if } 240 \mathrm{~nm} \leq D_{\mathrm{va}}<360 \mathrm{~nm} \\ 0.6 \cdot k+0.6 & \text { if } 360 \mathrm{~nm} \leq D_{\mathrm{va}}<700 \mathrm{~nm} \\ 1 & \text { if } D_{\mathrm{va}} \geq 700 \mathrm{~nm}\end{cases}$

$\kappa$ was estimated from particle chemical composition according to Eq. (3). On average the model overestimates the observations by $3 \%$; only in one case the model underpredicts the measured scavenging by $5 \%$ (absolute value).

Thereafter, we modeled organic scavenging based on the simulated nitrate size-segregated scavenging efficiency and the average mixing with nitrate:

$\eta_{\text {Org }} \bmod =\frac{\Sigma_{i}[\mathrm{Org}]_{i} \eta_{i} \operatorname{Mix} \Delta \log D_{\mathrm{va}_{i}} / \text { lens }_{i}}{\Sigma_{i}[\operatorname{Org}]_{i} \Delta \log D_{\mathrm{va}_{i}} / \text { lens }_{i}} ;$

$[\mathrm{Org}]_{i}$ is the concentration of organic in size bin $i$ before fog begins (as $d \mathrm{M} / d \log D_{\mathrm{va}}$ ), $\eta_{i}$ is the scavenging efficiency of nitrate calculated with Eq. (5), lens $s_{i}$ is the transmission efficiency of the aerodynamic lens of the HR-TOF-AMS, and Mix is the fraction of organic internally mixed with nitrate. For each fog event, Mix was estimated as the average ratio between organic and nitrate size-segregated scavenging efficiency. The difference between model and observation varies between -11 and $+8 \%$ (absolute values). The slightly larger discrepancy of OA scavenging is likely due to the simplified description of mixing with nitrate and the fact that the model does not include the effect of OA properties on its scavenging, such as hygroscopicity.

\section{Conclusions}

The employment of high time resolution techniques allowed for the investigation of chemical and microphysical properties of fine particles immediately before and after fog formation during 14 distinct fog events. 
The highest scavenging efficiencies were observed for nitrate, ammonium, and sulfate, at 70,68 , and $61 \%$, respectively. Scavenging of organic aerosol averaged $50 \%$, while the lowest values characterized black carbon (39\% on average).

Fog preferentially removed water-soluble components and oxidized organic aerosol in particles with a vacuum aerodynamic dry diameter larger than $400 \mathrm{~nm}$, leaving an interstitial aerosol enriched in water-insoluble and less oxidized carbonaceous species.

Although scavenging of water-soluble species like nitrate was close to completeness above $400 \mathrm{~nm} D_{\text {va }}$, it was strongly affected by chemical composition in smaller size ranges, especially when less water-soluble species like OA, were present. These results indicate that at very high relative humidity, OA affects significantly particle ability to take up water and form droplets. This implies that models require an accurate description of particle microphysics in order to describe both particle wet removal and atmospheric processing through heterogenous-phase chemistry.

Nucleation scavenging of OA varied between 45 and $63 \%$. A slight correlation between $\mathrm{O} / \mathrm{C}$ ratio and scavenging efficiency was observed. Nevertheless, the correlation of sizesegregated scavenging efficiency with that of nitrate, and the similarity of nitrate and OA size distributions before and after fog formation, suggests that organic scavenging was controlled by mixing with water-soluble inorganic species. The small variability of the degree of oxidation of OA and functional group composition during the experiment made it impossible to discriminate the role of OA composition on its scavenging.

To summarize, fog represents a significant sink of pollutants on a regional scale, especially in highly polluted areas characterized by cold winter and stagnant atmospheric conditions like the Po Valley. Here we have shown that scavenging is very efficient for nitrate and inefficient for BC. Scavenging of organic component is highly variable, and further studies are required to distinguish particle-mixing effects from organic composition effects.

\section{The Supplement related to this article is available online at doi:10.5194/acp-14-6967-2014-supplement.}

Acknowledgements. This research was funded by Regione Emilia Romagna as part of the "Supersito" project (DRG no. 428/10). The authors acknowledge L. Tarozzi and C. Carbone for their support during aerosol sampling activity, M. R. Canagaratna for her support during PMF analysis, and A. Freedman for providing the CAPS-PM instrument during the campaign.

Edited by: B. Ervens

\section{References}

Bond, T. C., Anderson, T. L., and Campbell, D.: Calibration and Intercomparison of Filter-Based Measurements of Visible Light Absorption by Aerosols, Aerosol Sci. Technol., 30, 582-600, 1999.

Carbone, C., Decesari, S., Mircea, M., Giulianelli, L., Finessi, E., Rinaldi, M., Fuzzi, S., Marinoni, A., Duchi, R., Perrino, C., Sargolini, T., Vardè, M., Sprovieri, F., Gobbi, G. P., Angelini, F., and Facchini, M. C.: Size-resolved aerosol chemical composition over the Italian Peninsula during typical summer and winter conditions, Atmos. Environ., 44, 5269-5278, 2010.

Chang, R. Y.-W., Slowik, J. G., Shantz, N. C., Vlasenko, A., Liggio, J., Sjostedt, S. J., Leaitch, W. R., and Abbatt, J. P. D.: The hygroscopicity parameter $(\kappa)$ of ambient organic aerosol at a field site subject to biogenic and anthropogenic influences: relationship to degree of aerosol oxidation, Atmos. Chem. Phys., 10, 5047-5064, doi:10.5194/acp-10-5047-2010, 2010.

Collett, JeffreyL., J., Sherman, D. E., Moore, K., Hannigan, M., and Lee, T.: Aerosol Particle Processing and Removal by Fogs: Observations in Chemically Heterogeneous Central California Radiation Fogs, Water Air Soil Poll. Focus, 1, 303-312, 2001.

Collett, J. L., Herckes, P., Youngster, S., and Lee, T.: Processing of atmospheric organic matter by California radiation fogs, Atmos. Res., 87, 232-241, 2008.

DeCarlo, P. F., Kimmel, J. R., Trimborn, A., Northway, M. J., Jayne, J. T., Aiken, A. C., Gonin, M., Fuhrer, K., Horvath, T., Docherty, K. S., Worsnop, D. R., and Jimenez, J. L.: Field-Deployable, High-Resolution, Time-of-Flight Aerosol Mass Spectrometer, Anal. Chem., 78, 8281-8289, 2006.

Decesari, S., Fuzzi, S., Facchini, M. C., Mircea, M., Emblico, L., Cavalli, F., Maenhaut, W., Chi, X., Schkolnik, G., Falkovich, A., Rudich, Y., Claeys, M., Pashynska, V., Vas, G., Kourtchev, I., Vermeylen, R., Hoffer, A., Andreae, M. O., Tagliavini, E., Moretti, F., and Artaxo, P.: Characterization of the organic composition of aerosols from Rondôonia, Brazil, during the LBASMOCC 2002 experiment and its representation through model compounds, Atmos. Chem. Phys., 6, 375-402, doi:10.5194/acp6-375-2006, 2006.

Duplissy, J., DeCarlo, P. F., Dommen, J., Alfarra, M. R., Metzger, A., Barmpadimos, I., Prevot, A. S. H., Weingartner, E., Tritscher, T., Gysel, M., Aiken, A. C., Jimenez, J. L., Canagaratna, M. R., Worsnop, D. R., Collins, D. R., Tomlinson, J., and Baltensperger, U.: Relating hygroscopicity and composition of organic aerosol particulate matter, Atmos. Chem. Phys., 11, 1155-1165, doi:10.5194/acp-11-1155-2011, 2011.

Dusek, U., Frank, G. P., Hildebrandt, L., Curtius, J., Schneider, J., Walter, S., Chand, D., Drewnick, F., Hings, S., Jung, D., Borrmann, S., and Andreae, M. O.: Size Matters More Than Chemistry for Cloud-Nucleating Ability of Aerosol Particles, Science, 312, 1375-1378, 2006.

Elbert, W., Hoffmann, M. R., Krämer, M., Schmitt, G., and Andreae, M. O.: Control of solute concentrations in cloud and fog water by liquid water content, Atmos. Environ., 34, 1109-1122, doi:10.1016/S1352-2310(99)00351-9, 2000.

Ervens, B., Turpin, B. J., and Weber, R. J.: Secondary organic aerosol formation in cloud droplets and aqueous particles (aqSOA): a review of laboratory, field and model studies, Atmos. Chem. Phys., 11, 11069-11102, doi:10.5194/acp-1111069-2011, 2011. 
Facchini, M. C., Fuzzi, S., Zappoli, S., Andracchio, A., Gelencsér, A., Kiss, G., Krivácsy, Z., Mészáros, E., Hansson, H.-C., Alsberg, T., and Zebühr, Y.: Partitioning of the organic aerosol component between fog droplets and interstitial air, J. Geophys. Res. Atmos., 104, 26821-26832, 1999a.

Facchini, M. C., Mircea, M., Fuzzi, S., and Charlson, R. J.: Cloud albedo enhancement by surface-active organic solutes in growing droplets, Nature, 401, 257-259, 1999 b.

Fuzzi, S., Orsi, G., Nardini, G., Facchini, M. C., McLaren, S., McLaren, E., and Mariotti, M.: Heterogeneous processes in the Po Valley radiation fog, J. Geophys. Res. Atmos., 93, 1114111151, 1988.

Fuzzi, S., Facchini, M. C., Orsi, G., Lind, J. A., Wobrock, W., Kessel, M., Maser, R., Jaeschke, W., Enderle, K. H., Arends, B. G., Berner, A., Solly, I., Kruisz, C., Reischl, G., Pahl, S., Kaminski, U., Winkler, P., Ogren, J. A., Noone, K. J., Hallberg, A., Fierlinger-Oberlinninger, H., Puxbaum, H., Marzorati, A., Hansson, H. C., Wiedensohler, A., Svenningsson, I. B., Martinsson, B. G., Schell, D., and Gerogii, H. W.: The Po Valley Fog Experiment 1989, Tellus B, 44, 448-468, 1992.

Gerber, H.: Direct measurement of suspended particulate volume concentration and far-infrared extinction coefficient with a laserdiffraction instrument, Appl. Optics, 30, 4824-4831, 1991.

Gilardoni, S., Liu, S., Takahama, S., Russell, L. M., Allan, J. D., Steinbrecher, R., Jimenez, J. L., DeCarlo, P. F., Dunlea, E. J., and Baumgardner, D.: Characterization of ambient aerosols during MIRAGE 2006 on three platforms, Atmos. Chem. Phys., 9, 5417-5432, doi:10.5194/acp-9-5417-2009, 2009.

Gilardoni, S., Vignati, E., Cavalli, F., Putaud, J. P., Larsen, B. R., Karl, M., Stenström, K., Genberg, J., Henne, S., and Dentener, F.: Better constraints on sources of carbonaceous aerosols using a combined $14 \mathrm{C}$-macro tracer analysis in a European rural background site, Atmos. Chem. Phys., 11, 5685-5700, doi:10.5194/acp-11-5685-2011, 2011

Gunthe, S. S., King, S. M., Rose, D., Chen, Q., Roldin, P., Farmer, D. K., Jimenez, J. L., Artaxo, P., Andreae, M. O., Martin, S. T., and Pöschl, U.: Cloud condensation nuclei in pristine tropical rainforest air of Amazonia: size-resolved measurements and modeling of atmospheric aerosol composition and CCN activity, Atmos. Chem. Phys., 9, 7551-7575, doi:10.5194/acp-9-75542009, 2009.

Hallberg, A., Ogren, J. A., Noone, K. J., Heintzenberg, J., Berner, A., Solly, I., Kruisz, C., Reischl, G., Fuzzi, S., Facchini, M. C., Hansson, H. C., Wiedensohler, A., and Svenningsson, I. B.: Phase partitioning for different aerosol species in fog, Tellus B, 44, 545-555, 1992.

Herckes, P., Chang, H., Lee, T., and Collett, JeffreyL., J.: Air Pollution Processing by Radiation Fogs, Water Air Soil Pollut/, 181, 65-75, 2007.

Hudson, J. G.: Variability of the relationship between particle size and cloud-nucleating ability, Geophys. Res. Lett., 34, L08801, doi:10.1029/2006GL028850, 2007.

Jimenez, J. L., Jayne, J. T., Shi, Q., Kolb, C. E., Worsnop, D. R., Yourshaw, I., Seinfeld, J. H., Flagan, R. C., Zhang, X., Smith, K. A., Morris, J. W., and Davidovits, P.: Ambient aerosol sampling using the Aerodyne Aerosol Mass Spectrometer, J. Geophys. Res. Atmos., 108, 8425, doi:10.1029/2001JD001213, 2003.
Jimenez, J. L., Canagaratna, M. R., Donahue, N. M., Prevot, A. S. H., Zhang, Q., Kroll, J. H., DeCarlo, P. F., Allan, J. D., Coe, H., Ng, N. L., Aiken, A. C., Docherty, K. S., Ulbrich, I. M., Grieshop, A. P., Robinson, A. L., Duplissy, J., Smith, J. D., Wilson, K. R., Lanz, V. A., Hueglin, C., Sun, Y. L., Tian, J., Laaksonen, A., Raatikainen, T., Rautiainen, J., Vaattovaara, P., Ehn, M., Kulmala, M., Tomlinson, J. M., Collins, D. R., Cubison, M. J., E., Dunlea, J., Huffman, J. A., Onasch, T. B., Alfarra, M. R., Williams, P. I., Bower, K., Kondo, Y., Schneider, J., Drewnick, F., Borrmann, S., Weimer, S., Demerjian, K., Salcedo, D., Cottrell, L., Griffin, R., Takami, A., Miyoshi, T., Hatakeyama, S., Shimono, A., Sun, J. Y., Zhang, Y. M., Dzepina, K., Kimmel, J. R., Sueper, D., Jayne, J. T., Herndon, S. C., Trimborn, A. M., Williams, L. R., Wood, E. C., Middlebrook, A. M., Kolb, C. E., Baltensperger, U., and Worsnop, D. R.: Evolution of Organic Aerosols in the Atmosphere, Science, 326, 1525-1529, 2009.

Kaul, D. S., Gupta, T., Tripathi, S. N., Tare, V., and Collett, J. L.: Secondary Organic Aerosol: A Comparison between Foggy and Nonfoggy Days, Environ. Sci. Technol., 45, 7307-7313, 2011.

Kebabian, P. L., Robinson, W. A., and Freedman, A.: Optical extinction monitor using cw cavity enhanced detection, Rev. Sci. Instr., 78, 063102, doi:10.1063/1.2744223, 2007.

Laaksonen, A., Korhonen, P., Kulmala, M., and Charlson, R. J.: Modification of the Köhler Equation to Include Soluble Trace Gases and Slightly Soluble Substances, J. Atmos. Sci., 55, 853862, 1998.

Levin, E. J. T., Prenni, A. J., Palm, B. B., Day, D. A., CampuzanoJost, P., Winkler, P. M., Kreidenweis, S. M., DeMott, P. J., Jimenez, J. L., and Smith, J. N.: Size-resolved aerosol composition and its link to hygroscopicity at a forested site in Colorado, Atmos. Chem. Phys., 14, 2657-2667, doi:10.5194/acp-14-26572014, 2014.

Li, Y. J., Lee, B. Y. L., Yu, J. Z., Ng, N. L., and Chan, C. K.: Evaluating the degree of oxygenation of organic aerosol during foggy and hazy days in Hong Kong using high-resolution time-offlight aerosol mass spectrometry (HR-ToF-AMS), Atmos. Chem. Phys., 13, 8739-8753, doi:10.5194/acp-13-8739-2013, 2013.

Liu, P. S. K., Deng, R., Smith, K. A., Williams, L. R., Jayne, J. T., Canagaratna, M. R., Moore, K., Onasch, T. B., Worsnop, D. R., and Deshler, T.: Transmission Efficiency of an Aerodynamic Focusing Lens System: Comparison of Model Calculations and Laboratory Measurements for the Aerodyne Aerosol Mass Spectrometer, Aerosol Sci. Technol., 41, 721-733, 2007.

Maria, S. F. and Russell, L. M.: Organic and Inorganic Aerosol Below-Cloud Scavenging by Suburban New Jersey Precipitation, Environ. Sci. Technol., 39, 4793-4800, 2005.

Maria, S. F., Russell, L. M., Turpin, B. J., Porcja, R. J., Campos, T. L., Weber, R. J., and Huebert, B. J.: Source signatures of carbon monoxide and organic functional groups in Asian Pacific Regional Aerosol Characterization Experiment (ACE-Asia) submicron aerosol types, J. Geophys. Res. Atmos., 108, 8637, doi:10.1029/2003JD003703, doi:10.1029/2003JD003703, 2003.

Massoli, P., Kebabian, P. L., Onasch, T. B., Hills, F. B., and Freedman, A.: Aerosol Light Extinction Measurements by Cavity Attenuated Phase Shift (CAPS) Spectroscopy: Laboratory Validation and Field Deployment of a Compact Aerosol Particle Extinction Monitor, Aerosol Sci. Technol., 44, 428-435, 2010.

Massoli, P., Fortner, E. C., Canagaratna, M. R., Williams, L. R., Zhang, Q., Sun, Y., Schwab, J. J., Trimborn, A., Onasch, 
T. B., Demerjian, K. L., Kolb, C. E., Worsnop, D. R., and Jayne, J. T.: Pollution Gradients and Chemical Characterization of $\neg \nmid$ Particulate $\neg \nmid$ Matter from Vehicular Traffic near Major Roadways: Results from the 2009 Queens College Air Quality Study in NYC, Aerosol Sci. Technol., 46, 1201-1218, doi:10.1080/02786826.2012.701784, 2012.

Middlebrook, A. M., Bahreini, R., Jimenez, J. L., and Canagaratna, M. R.: Evaluation of Composition-Dependent Collection Efficiencies for the Aerodyne Aerosol Mass Spectrometer using Field Data, Aerosol Sci. Technol., 46, 258-271, 2011.

Ming, Y. and Russell, L. M.: Organic aerosol effects on fog droplet spectra, J. Geophys. Res. Atmos., 109, D10206, doi:10.1029/2003JD004427, 2004.

Mohr, C., DeCarlo, P. F., Heringa, M. F., Chirico, R., Slowik, J. G., Richter, R., Reche, C., Alastuey, A., Querol, X., Seco, R., Peñuelas, J., Jiménez, J. L., Crippa, M., Zimmermann, R., Baltensperger, U., and Prévôt, A. S. H.: Identification and quantification of organic aerosol from cooking and other sources in Barcelona using aerosol mass spectrometer data, Atmos. Chem. Phys., 12, 1649-1665, doi:10.5194/acp-12-1649-2012, 2012.

Ng, N. L., Canagaratna, M. R., Zhang, Q., Jimenez, J. L., Tian, J., Ulbrich, I. M., Kroll, J. H., Docherty, K. S., Chhabra, P. S., Bahreini, R., Murphy, S. M., Seinfeld, J. H., Hildebrandt, L., Donahue, N. M., DeCarlo, P. F., Lanz, V. A., Prévôt, A. S. H., Dinar, E., Rudich, Y., and Worsnop, D. R.: Organic aerosol components observed in Northern Hemispheric datasets from Aerosol Mass Spectrometry, Atmos. Chem. Phys., 10, 46254641, doi:10.5194/acp-10-4625-2010, 2010.

Noone, K. J., Ogren, J. A., Hallberg, A., Heintzenberg, J., Strom, J., Hansson, H.-C., Svenningsson, B., Wiedensohler, A., Fuzzi, S., Facchini, M. C., Arends, B. G., and Berner, A.: Changes in aerosol size- and phase distributions due to physical and chemical processes in fog, Tellus B, 44, 489-504, 1992.

Onasch, T. B., Trimborn, A., Fortner, E. C., Jayne, J. T., Kok, G. L., Williams, L. R., Davidovits, P., and Worsnop, D. R.: Soot Particle Aerosol Mass Spectrometer: Development, Validation, and Initial Application, Aerosol Sci. Technol., 46, 804-817, 2012.

Paatero, P. and Tapper, U.: Positive matrix factorization: A nonnegative factor model with optimal utilization of error estimates of data values, Environmetrics, 5, 111-126, 1994.

Petters, M. D. and Kreidenweis, S. M.: A single parameter representation of hygroscopic growth and cloud condensation nucleus activity, Atmos. Chem. Phys., 7, 1961-1971, doi:10.5194/acp-71961-2007, 2007.

Petters, M. D. and Kreidenweis, S. M.: A single parameter representation of hygroscopic growth and cloud condensation nucleus activity - Part 2: Including solubility, Atmos. Chem. Phys., 8, 6273-6279, doi:10.5194/acp-8-6273-2008, 2008.

Putaud, J. P., Van Dingenen, R., Alastuey, A., Bauer, H., Birmili, W., Cyrys, J., Flentje, H., Fuzzi, S., Gehrig, R., Hansson, H. C., Harrison, R. M., Herrmann, H., Hitzenberger, R., Hüglin, C., Jones, A. M., Kasper-Giebl, A., Kiss, G., Kousa, A., Kuhlbusch, T. A. J., Löschau, G., Maenhaut, W., Molnar, A., Moreno, T., Pekkanen, J., Perrino, C., Pitz, M., Puxbaum, H., Querol, X., Rodriguez, S., Salma, I., Schwarz, J., Smolik, J., Schneider, J., Spindler, G., ten Brink, H., Tursic, J., Viana, M., Wiedensohler, A., and Raes, F.: A European aerosol phenomenology -3: Physical and chemical characteristics of particulate matter from 60 rural, urban, and kerbside sites across Europe, Atmos. Environ., 44, 1308-1320, 2010.

Quinn, P. K., Bates, T. S., Coffman, D. J., and Covert, D. S.: Influence of particle size and chemistry on the cloud nucleating properties of aerosols, Atmos. Chem. Phys., 8, 1029-1042, doi:10.5194/acp-8-1029-2008, 2008.

Russell, L. M., Takahama, S., Liu, S., Hawkins, L. N., Covert, D. S., Quinn, P. K., and Bates, T. S.: Oxygenated fraction and mass of organic aerosol from direct emission and atmospheric processing measured on the R/V Ronald Brown during TEXAQS/GoMACCS 2006, J. Geophys. Res. Atmos., 114, D00F05, doi:10.1029/2008JD011275, 2009.

Russell, L. M., Bahadur, R., and Ziemann, P. J.: Identifying organic aerosol sources by comparing functional group composition in chamber and atmospheric particles, Proc. Natl. Acad. Sci., 108, 3516-3521, 2011.

Saarikoski, S., Carbone, S., Decesari, S., Giulianelli, L., Angelini, F., Canagaratna, M., Ng, N. L., Trimborn, A., Facchini, M. C., Fuzzi, S., Hillamo, R., and Worsnop, D.: Chemical characterization of springtime submicrometer aerosol in Po Valley, Italy, Atmos. Chem. Phys., 12, 8401-8421, doi:10.5194/acp-12-84012012, 2012.

Seinfeld, J. H. and Pandis, S. N.: Atmospheric chemistry and physics : from air pollution to climate change, John Wiley \& sons, Inc., Hoboken, NJ, 777-840, 1998.

Shulman, M. L., Jacobson, M. C., Carlson, R. J., Synovec, R. E., and Young, T. E.: Dissolution behavior and surface tension effects of organic compounds in nucleating cloud droplets, Geophys. Res. Lett., 23, 277-280, 1996.

Sun, Y., Wang, Z., Fu, P., Jiang, Q., Yang, T., Li, J., and Ge, X.: The impact of relative humidity on aerosol composition and evolution processes during wintertime in Beijing, China, Atmos. Environ., 77, 927-934, 2013.

Ulbrich, I. M., Canagaratna, M. R., Zhang, Q., Worsnop, D. R., and Jimenez, J. L.: Interpretation of organic components from Positive Matrix Factorization of aerosol mass spectrometric data, Atmos. Chem. Phys., 9, 2891-2918, 2009, http://www.atmos-chem-phys.net/9/2891/2009/.

Whiteaker, J. R., Suess, D. T., and Prather, K. A.: Effects of Meteorological Conditions on Aerosol Composition and Mixing State in Bakersfield, CA, Environmental Science \& Technology, 36, 2345-2353, 2002.

Wobrock, W., Schell, D., Maser, R., Kessel, M., Jaeschke, W., Fuzzi, S., Facchini, M. C., Orsi, G., Marzorati, A., A., Winkler, P., Arends, B. G., and Bendix, J.: Meteorological characteristics of the Po Valley fog, Tellus B, 44, 469-488, doi:10.1034/j.16000889.1992.t01-4-00003.x, 1992.

Wyers, G. P., Otjes, R. P., and Slanina, J.: A continuousflow denuder for the measurement of ambient concentrations and surface-exchange fluxes of ammonia, Atmos. Environ.. Part A. General Topics, 27, 2085-2090, doi:10.1016/09601686(93)90280-C, 1993.

Zhang, Q., Jimenez, J. L., Canagaratna, M. R., Ulbrich, I. M., Ng, N. L., Worsnop, D. R., and Sun, Y.: Understanding atmospheric organic aerosols via factor analysis of aerosol mass spectrometry: a review, Anal. Bioanal. Chem., 10, 3045-3067, 2011. 